\title{
nature
}

\section{Europe trickles into space}

Next week's response from Europe to the US invitation to join in the space platform will be at best a compromise, at worst a nothing. Europe must make itself a policy.

PRESIDENT Ronald Reagan may have done Europe a service by his proposal that it should spend $\$ 2,000$ million on his $\$ 8,000$ million space station. At least he has knocked European heads together over an issue where European collaboration and expenditure certainly need to be enlarged if Europe is to play some part in the next stage of space technology, the building of large structures and the refurbishment of modular satellites in space. Sadly, the result, to be seen at a ministerial meeting of the European Space Agency in Rome next week, is likely to be a mess; but that is Europe's fault, not Reagan's.

The problem, essentially, is that the "European" space industry is not European, but national. National governments naturally back their national industries, with the result that decisions that should be commercial and market-led become highly politicized. This is mere pork-barrelling, and does not contribute much to the greater issues of European development.

European governments participating at Rome thus make great play with the issue of European "independence" from the United States in the control of, and access to, the space "infrastructure" represented by the proposed space station and its associated communications systems. On the one hand, this is presented as a great political issue, as by the French President M. François Mitterand in a speech in the Netherlands last year. But on the other, $\mathbf{M}$. Mitterrand is as much concerned about whether or not other states will back his French industry in the development of the \$900-million, winged "Hermès" mini-shuttle. Similarly, Britain will propose next week that technological (and possibly military) independence of the United States is only a distant issue, and that the question of putting Europe in space at all can be safely neglected for a time. Europe should back British Aerospace, the company which has proposed an experimental platform for polar or equatorial low-Earth orbit that would make no contact with the space station at all. Not being man-rated, the British flyer chalks up a much lower cost (perhaps by a factor of two) than the equivalent platform proposed by West Germany and Italy as part of the "Columbus" project. Britain, for the time being is therefore cool on men in space.

\section{Independence}

Columbus would come in two parts. There is a pressurized chamber, like Spacelab, for manned experiments, and a platform which can carry experiments as does the British Aerospace project, or dock with the pressure chamber to provide it with services. This would provide Europe with a poor man's independent space station - but only expensively. So one might expect West Germany, from self-interest, to take a middle position between France and the United Kingdom on "independence" from the United States. And this is exactly how the big countries of Europe line up, with Italy - which has a potential 25-30 per cent stake in Columbus - backing West Germany. Is this politics? Or is it business? And if the latter, is it good business? Either way, Europe seems unable to understand that the future prize may be much bigger than that now up for grabs.

That there is business to be won is attested by the Eurospace organization in Paris, which claims to speak for 60 of the largest aerospace companies in Europe. To 1993, Eurospace sees a market to European manufacturers of $\$ 1,800$ million a year in conventional launchers and satellites, and a microgravity market of $\$ 7,000$ million a year thereafter. And though the second figure is based on some "highly questionable" US studies, there is at least a possibility that there will be a market big enough to require that competing investments should be assessed on more serious commercial grounds than seems likely at next week's ministerial meeting in Rome.

Even internal national squabbles will play their part there. In West Germany, for example, the finance ministry has taken months to agree to back both the development of a cryogenic motor for Europe's conventional Ariane launcher and Columbus, and has then taken its pound of flesh by cutting the budget of the research technology ministry (BMFT), which the cabinet in Bonn has now decided must find 30-50 per cent of the cost of the programme, putting space science at risk.

\section{Veto}

Britain's space scientists are also in trouble. Although there seems to be broad support for a 15 per cent contribution to Columbus (if the British Aerospace machine can be considered part of it), opinions are divided over whether to raise the ESA mandatory subscription, supporting basic science by, 50 per cent in real terms over the next decade or so, another point on the ESA agenda for Rome (see p.259). This internal British problem could well become a European problem, for unwilling payers have a veto. According to ESA, a 7 per cent annual increase in the subscriptions (now totalling around $\$ 70$ million, paying for one scientific launch every two years or so) would of fer "reasonably relaxed" support for a detailed package of science missions for the next 20 years. This package, prepared over the past 18 months, has wide support in the scientific community in Europe as representing a minimum programme to keep Europe in business in space science. But according to ESA, the compromises it embodies would not survive a rate of increase of less than 5 per cent a year. Britain, however, offered only three per cent at the last ESA council meeting before Christmas. Will it be more generous next week?

Not only is three per cent insufficient to reach the Horizon 2000 threshold, but the British Science and Engineering Research Council, which has to pay the subscription, is in such straitened circumstances that it can hardly imagine paying even that. No wonder then that its council's head of science and (as it happens) the chairman of ESA, Dr Harry Atkinson, is talking hopefully of "leaky boxes". The leak he wants is out of the space budget of the Department of Trade and Industry, which will pay for participation in the space station, and into the budget of the council. Does he reckon without the stupefying bureaucratic isolations of departmental budgets in Britain, in which the tiniest leakage might seem a kind of public embezzlement?

Inflexibility probably also makes nonsense of the otherwise cogent arguments of Professor Martin Rees, the Cambridge astronomer, who says that space science is bound for decades to seem less cost-effective than the more modest schemes on which research councils think they should be spending money. Thus, Rees argues, the British contribution to the ESA mandatory budget should be hived off, to a British space agency, leaving the council room for better support for ground-based astronomy, among other things. All good sense, but no more likely to happen on that account. 